\title{
Vascular perfusion of the isolated rat stomach with a fluorocarbon emulsion
}

\author{
G A VAN HUIS* AND M F KRAMER
}

From the Department of Cell Biology, School of Medicine, University of Utrecht, Utrecht, The Netherlands

SUMMARY A constant-pressure system using a fluorocarbon (FC-75) containing artificial medium was used for vascular perfusion of the isolated rat stomach. A 10\% emulsion of FC-75 in a modified Tyrode solution, containing $3.5 \%$ bovine serum albumin, amino acids, nucleosides, and B-hydroxybutyrate appeared to allow an adequate perfusion for at least seven hours. The following criteria were used to estimate the functional state of the perfused stomach: (1) venous flow, (2) oxygen consumption, (3) leakage from the blood vessels to the gastric lumen, (4) ultrastructure, (5) secretion of $\mathrm{H}^{+}$and pepsinogen after stimulation, and (6) transport of labelled macromolecules. During perfusion oxygen consumption and venous flow remained, after an initial high value, constant for at least seven hours. Leakage from the vascular bed was absent. Ultrastructure was preserved for at least seven hours. Administration of pilocarpine led to secretion of $\mathrm{HCl}$ and pepsinogen. Pentagastrin and histamine stimulated $\mathrm{HCl}$ secretion in only some of the preparations. $\left[{ }^{3} \mathrm{H}\right]$-galactose was incorporated into macromolecules and transported from the Golgi-region towards the apex of the cell. These observations led to the conclusion that the described vascular perfusion system is at least an appropriate model for studying glycoprotein synthesis.

In earlier work the biosynthesis and secretion of pepsinogens ${ }^{1}$ and the biosynthesis and intracellular transport of glycoproteins in the surface mucous cells of the rat stomach ${ }^{2}$ were studied. The latter cells did not incorporate enough amino acids and galactose to allow a study of synthesis, intracellular transport, and secretion in vivo unless very high doses of radioactive precursor were used. Moreover, changes in the blood level of these precursors under varying conditionsfor example, fasting and feeding-could affect the rate of incorporation of an injected radioactive precursor by altering its specific radioactivity. To bypass these difficulties we incubated fragments of gastric mucosa. It appeared, however, that, although the specific radioactivity was high, only the surface mucous cells of these fragments incorporated the radioactive precursor present in the incubation fluid $^{\prime 2}$. As the concentration of a precursor, offered in this way, might decrease from the surface into the mucosal depth, no conclusions could be drawn as to the differences in synthetic capacity between younger

\footnotetext{
* Address for correspondence: Physiological Laboratory, Free University, Van der Boechorststraat 7, 1081 BT Amsterdam. The Netherlands.

Received for publication 16 February 1981
}

cells at the bottom of the gastric pits and older cells at the mucosal surface. Luminal perfusion ${ }^{3}$ and incubation of the whole stomach ${ }^{45}$ have the same disadvantages, but vascular perfusion of the isolated organ with an appropriate artificial medium combines the advantages of known medium composition, constant and high precursor specific radioactivity, and a natural distribution of substrates over the tissues. Hence we decided to develop such a perfusion system for the rat stomach.

The stomach is very oxygen dependent, so that a decrease of oxygen supply leads to loss of energy charge within minutes, ${ }^{6}$ immediate disappearance of mucosal potential difference, ${ }^{7}$ and even necrosis. ${ }^{6}$ The oxygen dependence, however, varies with the cell type. Smooth muscle function may remain intact, while the mucosal cells are damaged. The parietal cells, in particular, are susceptible to hypoxic damage. We tried to avoid a shortage of oxygen by preventing interruption of the oxygen supply during the isolation of the stomach. As we used a perfusion medium containing a fluorocarbon, a carrier of oxygen well-known since Gollan and Clark ${ }^{8}$ published their results, ${ }^{910}$ oxygen content was abundant during the perfusion. 
Table 1 Composition of media

\begin{tabular}{|c|c|c|c|c|c|c|c|}
\hline \multicolumn{2}{|c|}{ Medium A. Modified after Tyrode ${ }^{27}$} & \multicolumn{2}{|c|}{ Medium B. Fluorocarbon emulsion } & \multicolumn{4}{|c|}{ Amino acid mixture: $(\mathrm{mg} / 100 \mathrm{ml}$ stock solution, final $\mathrm{pH}$ 10.0) } \\
\hline $\begin{array}{l}\mathrm{NaCl} \\
\mathrm{KCl} \\
\mathrm{CaCl}_{2} \\
\mathrm{MgCl}_{2} \\
\mathrm{NaHCO}_{3} \\
\mathrm{NaH}_{2} \mathrm{PO}_{4} \\
\mathrm{Glucose} \\
\text { Ampicillin } \\
\text { Heparin }\end{array}$ & $\begin{array}{c}137.0 \mathrm{mN} \\
5.9 \mathrm{mM} \\
1.8 \mathrm{mM} \\
0.5 \mathrm{mM} \\
25.0 \mathrm{mM} \\
0.4 \mathrm{mM} \\
5.9 \mathrm{mM} \\
0.02 \mathrm{mg} / \mathrm{ml} \\
10.0 \mathrm{IU} / \mathrm{ml}\end{array}$ & $\begin{array}{l}100 \mathrm{ml} \\
10 \mathrm{ml} \\
\\
2 \mathrm{~g} \\
3.5 \mathrm{~g} \\
5.7 \mathrm{mM} \\
1.25 \mathrm{ml} \\
0.1 \mathrm{mM}\end{array}$ & $\begin{array}{l}\text { Medium A } \\
\text { Fluorocarbon FC-75, } \\
\text { dispersed with } \\
\text { F-68 detergent } \\
\text { Dialysed bovine serum } \\
\text { albumin } \\
\text { B-hydroxybutyrate } \\
\text { Mixture of amino acids in } \\
\text { plasma concentration } \\
\text { Nucleosides: adenosine, } \\
\text { cytidine, guanosine, and } \\
\text { uridine }\end{array}$ & $\begin{array}{l}\text { Tyrosine } \\
\text { Cystine } \\
\text { Arginine } \\
\text { Asparagine- } \mathrm{HCl} \\
\text { Asparagine } \\
\text { Glutamine } \\
\text { Glutamine- } \mathrm{HCl} \\
\text { Threonine } \\
\text { Serine } \\
\text { Glycine } \\
\text { Alanine }\end{array}$ & $\begin{array}{r}131 \\
115 \\
218 \\
43 \\
493 \\
479 \\
170 \\
229 \\
244 \\
240 \\
249\end{array}$ & $\begin{array}{l}\text { Valine } \\
\text { Methionine } \\
\text { Isoleucine } \\
\text { Leucine } \\
\text { Phenylalanine } \\
\text { Histidine } \\
\text { Lysine } \\
\text { Proline } \\
\text { Cysteine } \\
\text { Tryptophan }\end{array}$ & $\begin{array}{r}197 \\
72 \\
105 \\
165 \\
93 \\
101 \\
730 \\
198 \\
100 \\
114\end{array}$ \\
\hline
\end{tabular}

Final osmolality: $320 \mathrm{mOsm} / \mathrm{kg}$

Final pH: $7 \cdot 35$

*In demineralised water.

\section{Methods}

\section{CHEMICALS}

The fluorocarbon FC-75 was obtained from 3Mcompany (St. Paul, Minn., USA), bovine serum albumin came from Organon (Oss, The Netherlands) and F-68 detergent was a gift from Nefran Chemie (Amsterdam, The Netherlands). The stimulants used were pentagastrin (Peptavlon, ICI, Macclesfield, Cheshire, UK), pilocarpine nitrate (Merck, Darmstadt, W-Germany), and histamine-dihydrochloride (Sigma, St. Louis, Mo., USA). [ $\left.{ }^{3} \mathrm{H}\right]$-galactose and $\left[{ }^{3} \mathrm{H}\right]$-serine were from the Radiochemical Centre (Amersham, Bucks., UK). All other chemicals were of analytical grade, from Merck.

\section{EXPERIMENTAL ANIMALS}

Male Wistar rats (TNO, Zeist, The Netherlands), were fed a standard chow from Hope Farms (Woerden, The Netherlands). Animals, weighing $150-200 \mathrm{~g}$, were fasted for 18 hours, with free access to water.

\section{PERFUSION MEDIA}

In a series of experiments, the composition of the perfusion fluid was varied to obtain a composition that maximally met the criteria of good perfusion that will be described in the results section. The composition of the media ultimately used is described in Table 1. Their osmolalities were determined with an osmometer (Advanced Instruments, Newton Highlands, Mass., USA). The fluorocarbon medium (B) was prepared after Ruigrok and Elbers. ${ }^{9}$ Additions were made as set out in Table 1. Occasionally Evans' Blue (1 mg of a neutralised solution in Tyrode) was added to the circulating medium as an indicator of intercellular fluid loss. ${ }^{11}$ Medium B can be stored at $-20^{\circ} \mathrm{C}$, and is ready for use after thawing. Medium B was sonicated and filtered through a 5- $\mu \mathrm{m}$ Millipore filter before use. After gassing with $95 \% \mathrm{O}_{2} / 5 \% \mathrm{CO}_{2}$, the $\mathrm{pH}$ was $7 \cdot 35$.
PERFUSION SYSTEM

Rats were anaesthetised by intraperitoneal injection of $0.5 \mathrm{ml} 25 \%(\mathrm{w} / \mathrm{v})$ urethane in $0.9 \% \mathrm{NaCl}$ per $100 \mathrm{~g}$ body weight. The abdominal cavity was opened and the stomach was cleared from its ligaments. The splenic artery and the tributaries of the right gastric and gastroduodenal arteries to the duodenum, spleen, and pancreas were tied, and the pancreas and spleen were removed. The hepatic artery, the cranial mesenteric artery, and the right renal artery were tied and cut. Duodenum and oesophagus were cannulated. After injection of 500 IU heparin in the tail vein, the aorta was clamped caudal from the coeliac artery, cannulated, and connected to the perfusion system. After removing the haemostat, the blood was oscillating in the cannula, so that the perfusion pressure appeared to equal the mean blood pressure. Perfusion started when the aorta was tied and cut, rostral to the origin of the coeliac artery. The portal vein was opened, and the isolated stomach placed in the water-jacketed organ bath. In this way blood was immediately replaced by warm oxygenated medium A from reservoir 1 . After five minutes of preperfusion most of the blood had been washed out, and the stomach was perfused by medium $B$ (containing fluorocarbon) from reservoir 2 . After three hours of recirculating, medium B was replaced by fresh medium. The perfusion medium, leaving the stomach via the opened portal vein into the organ bath, passed through a flow cuvette (Radiometer DS 66014, Copenhagen, Denmark), equipped with $\mathrm{pH}$ and $\mathrm{pO}_{2}$ electrodes. The $\mathrm{pH}$ and $\mathrm{pO}_{2}$ were measured continuously with a $\mathrm{pH} / \mathrm{pO}_{2}$ module (Radiometer PHM 71 Mk 2) connected to a linear recorder. The medium was then filtered through a standard infusion filter and pumped back into the reservoir by a calibrated rollerpump (Ismatec MP/GE 4, Cenco, Breda, The Netherlands). By adjusting the rollerpump so that the fluid level in the filter was kept constant, we could determine the flow rate. 
The perfusion medium was oxygenated in the reservoirs by means of membrane oxygenators, consisting of a length of $2 \mathrm{~m}$ of thin-walled silicone tubing. ${ }^{12}$ The pressures of the outflowing gas, and therefore of the perfusion fluid, was regulated by a water column of $120 \mathrm{~cm}$ in length, which is equal to the mean diastolic blood pressure. Venous pressure was kept at $10 \mathrm{~cm}$ of water. All other tubing was neoprene rubber, so that little oxygen was lost in the circuit. The flow of oxygen through the silicone tubing was sufficient to compensate for the consumption of oxygen by the stomach: the $\mathrm{pO}_{2}$ of the medium leaving the reservoir was $80 \mathrm{kPa} \pm 1 \quad(:$ SEM $\mathrm{n}=24 ;=603 \mathrm{mmHg} \pm 10$ ) with and without a stomach in the organ bath. The variance of the $\mathrm{pO}_{2}$ of the perfusion medium entering the stomach is small enough to be neglected, and the venous $\mathrm{pO}_{2}$ could be used to calculate the oxygen consumption by the perfused stomach.

The reservoirs, organ bath and electrodes were kept at a constant temperature $\left(38 \cdot 0^{\circ} \mathrm{C} \pm 0 \cdot 1\right)$ by water-jackets.

An isomolar solution of the inert polyethylene glycol-1500 (23\% w/v $320 \mathrm{mOsm} / \mathrm{kg}, \mathrm{pH} 5.0)$ was infused into the stomach lumen though the oesophagal stump at a rate of $12 \mathrm{ml} / \mathrm{h}$. The lumen fluid was aspirated from the cannulated duodenal stump through a smaller tube, so that the lumen was not evacuated. The $\mathrm{pH}$, volume, titratable $\mathrm{H}^{+}$, and pepsinogen content of this fluid were determined.

\section{CHEMICAL DETERMINATIONS}

The titratable $\mathrm{H}^{+}$-concentration was determined by titrating the lumen fluid to $\mathrm{pH} 8 \cdot 0$ with $0 \cdot 1 \mathrm{~N} \mathrm{NaOH}$. The infusion fluid has no buffering capacity. The concentrations of $\mathrm{Na}^{+}$and $\mathrm{K}^{+}$were determined with a Flame Photometer 143 (Instrumentation Laboratory Inc., Boston, Mass., USA), the concentration of $\mathrm{Cl}^{-}$ with a Chloro-counter (Marius, Utrecht, The Netherlands).

Anson's method for the estimation of pepsin (1938) was modified: the final volume was $1 \mathrm{ml}$, incubation took place at $37^{\circ} \mathrm{C}$, and the concentration of hydrolysed products was measured at $278 \mathrm{~nm}$. Activity was expressed in pepsin-units (PU) according to Anson. ${ }^{13}$

\section{MORPHOLOGY AND AUTORADIOGRAPHY}

At the end of a perfusion experiment the stomach was fixed by vascular perfusion of the stomach with glutaraldehyde and formaldehyde in $0.1 \mathrm{M}$ phosphate buffer $(\mathrm{pH} \mathrm{7.4)}$ each in concentrations of $1 \%$, with $1 \%$ saccharose added. After perfusion longitudinal strips from the greater curvature were placed in a fresh volume of fixative during one hour. The strips were washed overnight at $4^{\circ} \mathrm{C}$ in Tyrode's solution, postfixed in $1 \% \mathrm{OsO}_{4}$ for two hours at $4^{\circ} \mathrm{C}$, and dehydrated in graded ethanol solutions at $4^{\circ} \mathrm{C}$. The strips were divided into cubes and embedded in Epon 812.

One- $\mu$ m-thick sections were cut on a Sorvall (Newton, Conn., USA) Porter-Blum MT-1 microtome. For LM-autoradiography sections were pretreated with $\mathrm{NaOH}$ and periodic acid, before covering with Kodak AR-10 stripping film; dried, and stored at $4^{\circ} \mathrm{C}$ for 21 (galactose) or 14 (serine) days. After developing, the sections were stained with Azur-II-methylene Blue. ${ }^{14}$ Silver grains were counted over three regions in the surface mucous cells, as will be described below.

\section{Results}

PERFUSION EXPERIMENTS

The quality of a perfusion was first estimated from (1) the venous flow, (2) the oxygen consumption, and (3) maintenance of normal vascular permeability and absence of oedema. If, based on these characteristics, the perfusion was judged to be undisturbed, the stomach was fixed, and (4) its ultrastructure studied. Under the guidance of these four criteria perfusion circumstances could be improved stepwise. Heavy sonication and filtering (5 $\mu \mathrm{m}$ Millipore) of the medium before use, and change of the medium after three hours appeared to be necessary to ensure reproducible perfusions during periods longer than three hours.

Eagle's basal medium (Flow Laboratories, Irvine, Scotland) with $3 \cdot 5-4 \cdot 5 \%$ BSA and $10 \%$ fetal calf serum (Difco, Detroit, Mich., USA) was used in nine experiments. In four of them $10 \%$ fluorocarbon was added. All these media gave no obviously better results than $10 \%$ fluorocarbon and $3.5 \%$ BSA in Tyrode. Addition of papaverine $(1 \mathrm{mg} / 30 \mathrm{ml})$ or isoprenaline $(1 \mathrm{ng} / 30 \mathrm{ml})$ to widen the gastric blood vessels did not improve perfusion. Washed human erythrocytes, suspended in an equal volume of Tyrode with BSA (final concentration $3.5 \%$ ), were used in two experiments. The venous flow rate was low; sections showed many erythrocytes in the submucosal connective tissue.

\section{Venous flow}

The venous flow appeared to be the most reliable and quickest criterion during perfusion. It remained rather constant after the first hour of perfusion (statistical test for constancy: $\mathbf{P}<0 \cdot 01$ ). Flow is minimal during the fifth hour of perfusion (Table 2). Experiments with a flow of less than $0.5 \mathrm{ml} / \mathrm{min}$ (over a 10 minute interval) were discarded.

\section{Oxygen consumption}

The oxygen consumption by the perfused stomach 
Table 2 Summary of all experiments with normal venous flow, oxygen consumption and secretory volume*

\begin{tabular}{llll}
\hline $\begin{array}{l}\text { Perfusion } \\
\text { time }(h)\end{array}$ & $\begin{array}{l}\text { Expts. } \\
\text { (no.) }\end{array}$ & $\begin{array}{l}\text { Venous flow } \\
(\text { ml/min) }\end{array}$ & $\begin{array}{l}\text { Oxygen consumption } \\
(\mu \mathrm{mol} / \mathrm{min})\end{array}$ \\
\hline 1 & 21 & $3 \cdot 4 \pm 0 \cdot 4$ & $2 \cdot 0 \pm 0 \cdot 2$ \\
2 & 21 & $2 \cdot 1 \pm 0 \cdot 3$ & $1 \cdot 3 \pm 0 \cdot 2$ \\
3 & 18 & $1 \cdot 5 \pm 0 \cdot 2$ & $1 \cdot 0 \pm 0 \cdot 2$ \\
4 & 10 & $1 \cdot 2 \pm 0 \cdot 3$ & $0 \cdot 9 \pm 0 \cdot 2$ \\
5 & 6 & $1 \cdot 1 \pm 0 \cdot 4$ & $0 \cdot 7 \pm 0 \cdot 2$ \\
6 & 5 & $1 \cdot 4 \pm 0 \cdot 3$ & $0 \cdot 8 \pm 0 \cdot 3$ \\
7 & 5 & $2 \cdot 1 \pm 0 \cdot 4$ & $0 \cdot 8 \pm 0 \cdot 3$ \\
\hline
\end{tabular}

*The short-term experiments were also included in this Table, these were not terminated because of faulty perfusion. Means $\pm S E M$.

can be calculated from the flow and the difference in oxygen concentration between the 'arterial' and 'venous' perfusion medium. The oxygen concentrations were derived from the $\mathrm{pO}_{2}$ values. The arterial value appeared to be constant (see Methods) and the venous value was measured in the flow cuvette. Data on the solubility of oxygen in fluorocarbon at $38^{\circ} \mathrm{C}$ at various partial pressures of oxygen have been published by Zander. ${ }^{15}$ The oxygen consumption decreased very slightly, but not significantly (test for constancy: $\mathbf{P}<0.01$ ) after the second hour of perfusion (Table 2). The rather high value during the first hour was presumably caused by the preperfusion wash with medium $\mathrm{A}$, having a relatively low oxygen content, due to the absence of the fluorocarbon emulsion. As the duration of the high oxygen consumption increased with the length of preperfusion,

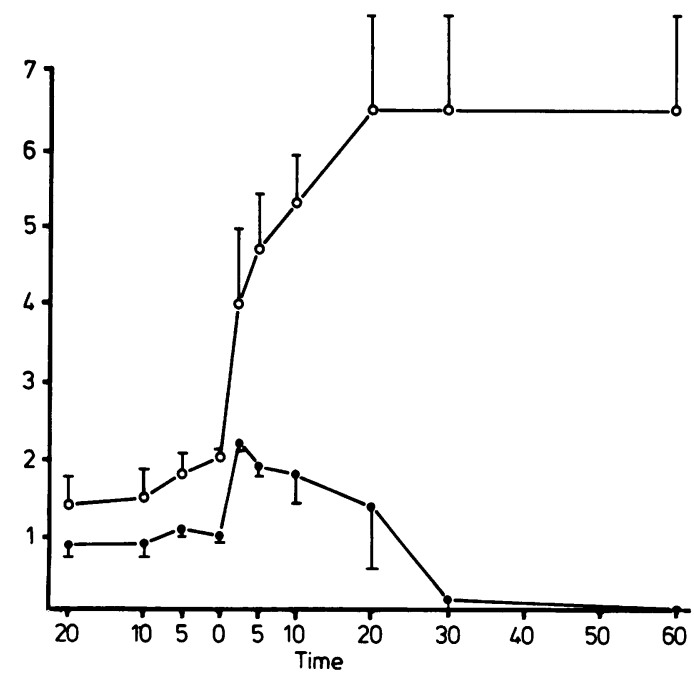

Fig. 1 Effect of DNP on flow and oxygen consumption. Means of four experiments $\pm S E M$. DNP was added after three hours of perfusion (at the time indicated by zero at the abscissa). ○- flow ( $\mathrm{ml} / \mathrm{min})$. O oxygen consumption ( $\mu \mathrm{mol} / \mathrm{min})$ the wash with medium A might have caused an initial oxygen debt in the tissues. Experiments in which the oxygen consumption decreased to $0 \cdot 2 \mu \mathrm{mol} / \mathrm{min}$ or less were discarded.

\section{Net fluid flow to gastric lumen}

Net fluid flow to gastric lumen (secretion and/or transudation) was determined by subtracting the volume infused into the lumen from the volume aspirated at the duodenal stump. It amounted to about $5 \mathrm{ml}$ per hour; it increased the $\mathrm{pH}$ of the luminal perfusion fluid from $5 \cdot 0$ to about $8 \cdot 0$. In preparations discarded because of the too-low venous flow $(<0.5 \mathrm{ml} / \mathrm{min})$, much more fluid was produced. When in those cases Evans' Blue was added to the vascular perfusion medium, the lumen fluid was coloured blue.

\section{Ultrastructure}

Under optimal conditions (venous flow $>0.5 \mathrm{ml} / \mathrm{min}$, oxygen consumption $>0.2 \mu \mathrm{mol} / \mathrm{min}$, lumen fluid volume $<5 \mathrm{ml} / \mathrm{h}$ ) the normal ultrastructure of the perfused stomach appeared to be preserved during at least seven hours, as was shown by these authors. ${ }^{16}$ Even when in some parts of these stomachs the intercellular spaces between the basal parts of the surface mucous cells were dilated, their ultrastructure was normal. Dilated intercellular spaces were also observed in stomachs after some minutes of perfusion.

\section{EFFECT OF RESPIRATORY INHIBITORS}

In order to test the function of the energy supply system, potassium cyanide (final concentration $1 \mathrm{mM})$ of dinitrophenol (DNP, final concentration 1 $\mathrm{mM}$ ) were added to the perfusion medium in the reservoir, after three hours of perfusion. KCN blocked the oxygen consumption immediately. After DNP addition the oxygen consumption decreased after an initial increase (Fig. 1). The venous flow rate increased after DNP or KCN addition.

\section{STIMULATION OF SECRETION}

To study whether the chief and parietal cells are functional, pilocarpine (in doses of $0.4,0.8$, or 3.2 $\mathrm{mg}$, dissolved in Tyrode), histamine (45 or $100 \mu \mathrm{g})$, or pentagastrin $(5,16$, or $128 \mu \mathrm{g})$ were added to the perfusion medium as a bolus injection via the arterial cannula. Volume, $\mathrm{pH}$, and titratable acid of the aspirated lumen fluid, and its pepsinogen content were determined. $\mathrm{Na}^{+}, \mathrm{K}^{+}$, and $\mathrm{Cl}^{-}$concentrations in the lumen fluid were also determined, but because of the relatively high luminal perfusion rate, they were too low to show measurable secretory effects. In a few cases histamine and pentagastrin caused an increase of the titratable $\mathrm{H}^{+}$content of the luminal fluid, or an 
increased pepsinogen secretion, but these effects were not significant. In Fig. 2 the effect of pilocarpine is shown, in the optimal steady state concentration of $20 \mu \mathrm{g} / \mathrm{ml}$ medium ( $=0.4 \mathrm{mg}$ injection). In six out of eight experiments it caused a significant rise in pepsinogen and titratable $\mathrm{H}^{+}$content, and a fall in $\mathrm{pH}$. In two of these six experiments the effects were more pronounced than in the others: the $\mathrm{pH}$ decreased from 7.5 to 4.0 and 2.5 respectively. Oxygen consumption and venous flow were slightly (but not significantly) higher during stimulation.

\section{SYNTHESIS AND INTRACELLULAR.TRANSPORT OF} GLYCOPROTEINS DURING PERFUSION

To study whether the mucous cells are functionally undisturbed during the perfusion, $\left[{ }^{3} \mathrm{H}\right]$-galactose was added to the perfusion medium (final concentration $10 \mu \mathrm{Ci} / \mathrm{ml}) 10$ minutes after transfer to the organ bath. Ten minutes later this medium was replaced by one containing $1 \mathrm{mg} / 30 \mathrm{ml}$ of unlabelled galactose. After three weeks of exposure, the number of silver grains amounted to about six per cell. Silver grains were contributed to three regions of the surface

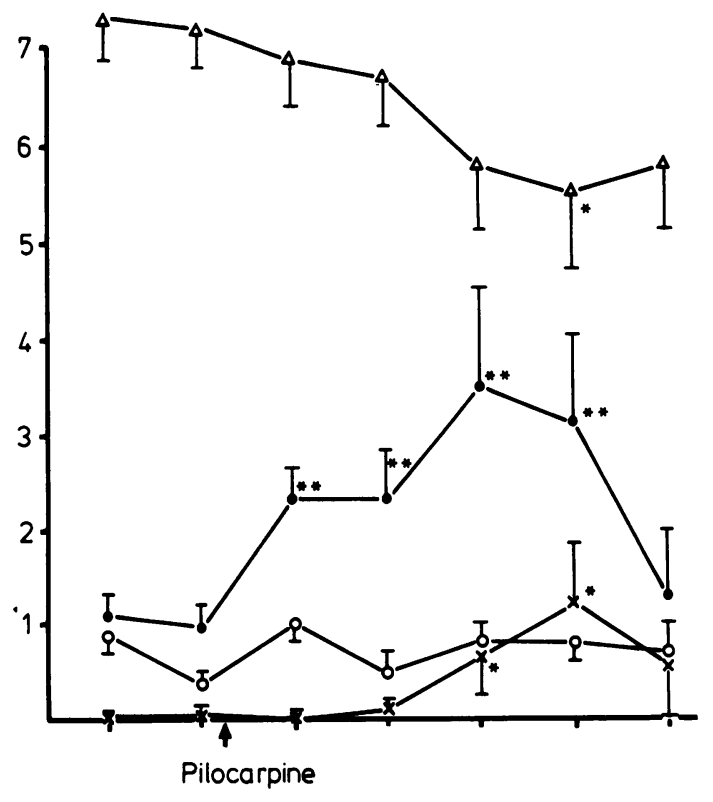

10 fractions

Fig. 2 Effect of cholinergic stimulation on net volume, $p H$, titratable $\mathrm{H}^{+}$, and pepsinogen secretion in aspirated lumen fluid. Means of six experiments $\pm S E M$. The 10 minute values that differ significantly from the value before stimulation (first two fractions) are marked with * $(\mathrm{P}<0.05)$ or ${ }_{* *}(\mathrm{P}<0 \cdot 01)$. Pilocarpine was added between one and two hours of perfusion $\mathrm{O}-\mathrm{O}$ volume $(\mathrm{ml} / 10 \mathrm{~min})$. $(0 \cdot 1 \mathrm{pu} / 10 \mathrm{~min}) . \times-\times H^{+}(10 \mu \mathrm{eq} / 10 \mathrm{~min}) . \triangle-\triangle p H$.

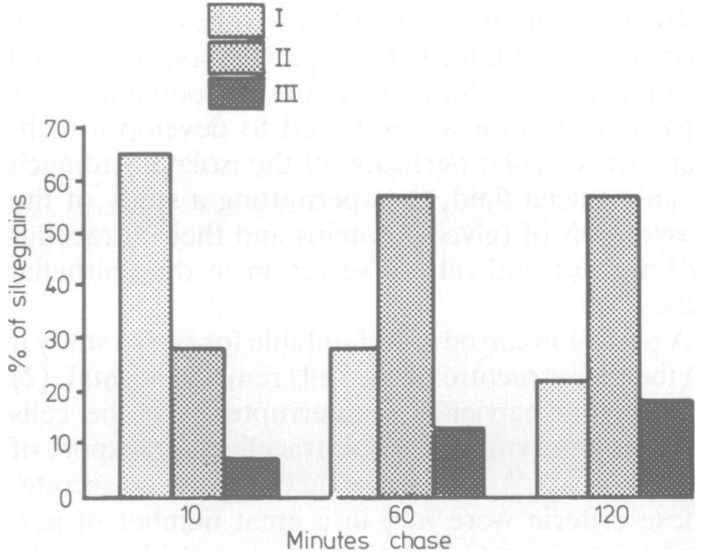

Fig. 3 Relative frequency of silver grains over three regions of surface mucous cells, 10, 60, or 120 minutes after 10 minutes of perfusion with $\left.10 \mu \mathrm{Ci} / \mathrm{ml}^{3}{ }^{3} \mathrm{H}\right]$-galactose. Region I: supranuclear, region II: intermediate, region III: secretory granules. Silver grains (about 1400) were counted over 250 surface mucous cells in autoradiographs from each stomach. The distribution of silver grains between the two stomachs used for each interval was not significantly different. Hence the numbers of silver grains over both stomachs were taken together. The poisson error was $0 \cdot 5-1 \cdot 5 \%$.

mucous cells: region I, aside and apical from the nucleus (Golgi zone); region II, the region between the nucleus and the secretory granules (containing RER and condensing vacuoles); region III, secretory granules. After 10 minutes of incubation in medium with unlabelled galactose $65 \%$ of the silver grains were found over I, after two hours only $20 \%$; labelled macromolecules were transported to region II $(48 \%$ after one hour) and further to the mature secretory granules (20\% after two hours; Fig. 3). From these grain counts it can be concluded that (1) galactose was used for synthesis, not just absorbed, because silver grains were not evenly distributed over the cells, and (2) labelled macromolecules were transported from the site of synthesis to the site of storage. When $\left[{ }^{3} \mathrm{H}\right]$-serine was used, most silver grains were found over region II (RER) after 10 minutes: over region I (Golgi), region II (condensing vacuoles), and region III (secretory granules) at later intervals.

\section{Discussion}

So far only motility and secretion of $\mathrm{HCl}$ have been studied in canine and porcine stomachs, perfused $e x$ vivo. ${ }^{17}{ }^{18}$ In these studies $\mathrm{HCl}$ secretion could not be stimulated, unless a supporting animal was incorporated in the perfusion circuit for oxygenating and detoxicating the perfusion blood. ${ }^{17}{ }^{19-23}$ However, in using a supporting animal the main advantage of iso- 
lated perfusion for studies of biosynthesis is lost; the high specific radioactivity of precursors, unaffected by an unknown dilution by pools in blood and other organs. Therefore we preferred to develop a technique for vascular perfusion of the isolated stomach by an artificial fluid, thus permitting a study of the biosynthesis of (glyco-)proteins and their intracellular transport and rate of secretion in the epithelial cells.

A perfusion can be called suitable for such a study if (1) the ultrastructure of the cells remains normal, (2) the mucosal barrier is uninterrupted, (3) the cells continue the synthesis and intracellular transport of glycoproteins, ${ }^{16}$ and keep their ability to secrete. These criteria were met in a great number of perfusion experiments. During perfusions with suboptimal preservation of these characteristics, the oxygen consumption was too low, while Evans' Blue leaked into the lumen. Evans' Blue binds to the albumin in the perfusion fluid, and hence its appearance in the lumen fluid indicates the presence of a break in the mucosal barrier. ${ }^{1124}$ In the case of a suboptimal perfusion the venous flow can either be lower $(<0.5$ $\mathrm{ml} / \mathrm{min})$ or sometimes higher $(<5 \mathrm{ml} / \mathrm{min})$ than in successful preparations. A low venous flow is likely to be caused by obstructions in the blood vessels; high flow can be brought about by unnoticed leaks in the arterial supply to the stomach, caused by damage during the isolation procedure. The opening of the arteriovenous shunts is not a likely explanation, for their existence in the stomach has not been demonstrated conclusively. In both cases the mucosa received an insufficient amount of oxygen, and disintegrates; the parietal cells disappear first, followed by surface mucous cells, chief cells, and parts of the lamina propria.

Even during successful perfusions the oxygen consumption decreased gradually, but reached a basal level after the second hour. Way and Hawley ${ }^{23}$ reported a venous flow rate of $0.4 \mathrm{ml} / \mathrm{min} / \mathrm{g}$ wet fundus, and an oxygen consumption of $6.5 \mu \mathrm{l} / \mathrm{min} / \mathrm{g}$ in perfused dog stomach. Our values were $5 \cdot 1$ $\mathrm{ml} / \mathrm{min} / \mathrm{g}$ and $67.2 \mu \mathrm{l} / \mathrm{min} / \mathrm{g}$ during the first, and 1.6 $\mathrm{ml} / \mathrm{min} / \mathrm{g}$ and $22.4 \mu \mathrm{l} / \mathrm{min} / \mathrm{g}$ during the fifth hour. So even our basic values are still relatively high. The observed arteriovenous difference in $\mathrm{pO}_{2}$ during perfusion was caused by mitochondrial respiration and not by leakage of oxygen from the perfusion system, as addition of DNP or KNC to the perfusion fluid decreased the oxygen consumption to zero. DNP initially doubled the oxygen consumption, indicating that the respiration was uncoupled. The subsequent decrease of oxygen consumption was obviously brought about by disintegration of the mitochondria by lack of energy. The increased venous flow accompanying the decreasing oxygen consumption after the addition of KNC or DNP might be caused by a relaxation of the muscular layer of the bloodvessels by lack of newly generated ATP.

It should be noted that the perfused stomach produced a slightly alkaline fluid at a rate of about 5 $\mathrm{ml} / \mathrm{h}$, also when no stimulating drugs had been administered. This alkalinity might represent the product of non-parietal secretion, as suggested by Kowalewski and Scharf, ${ }^{20}$ and/or a leakage through the mucosa. The expanded space between the surface mucous cells might be related to ionic transport in favour of non-parietal secretion. The tight-junctions between the cells, however, were functionally intact, for they did not permit the passage of Evans' Blue. An observed slight decrease of the $\mathrm{pH}$ of the vascular perfusion medium during the perfusion might be related to a loss of bicarbonate into the gastric lumen.

The duration of the perfusions was arbitrarily limited to seven hours, although under the defined conditions the ultrastructure of all mucosal cell types was still well preserved after that interval, and the gastric wall showed its normal tone and thickness.

It appeared to be possible to stimulate the secretion of pepsinogen in these ex vivo perfused stomach preparations. The secretion of $\mathrm{H}^{+}$-ions could also be stimulated without the aid of a supporting animal: cholinergic stimulation with pilocarpine was effective to a varying extent in most experiments; pentagastrin and histamine, however, failed to evoke a measurable response in most cases. From these observations can be concluded that even by using the method of perfusion described here, guaranteeing a continuous high oxygen content, impairment of parietal cell function was not prevented. Obviously other factors are playing a role. Pilot $^{25}$ recently demonstrated an increase in concentration of inhibitors of proton secretion during isolated perfusion of the canine stomach.

Incorporation of tritiated galactose and serine, however, was very reproducible. Label was incorporated into macromolecules and transported through the cell along the generally known route: (RER)Golgi-condensing vacuoles-secretory granules. By using the perfusion system described in this paper, we were recently able to compare the rate of incorporation of a number of precursors in the surface mucous cells in the various parts of the gastric mucosa,${ }^{16}$ and in the fundic foveolar cells of different age.$^{26}$ Studies are under way to study the effect of various drugs on the synthesis of glycoproteins.

From the evidence presented here, in combination with the preservation of the ultrastructure of all cells of the gastric mucosa, it can be concluded that vascular perfusion of rat stomach is a valuable technique for the study of the biosynthesis of pepsinogen and muco-substances. 
The authors wish to thank Dr T C J Ruigrok, who helped us with the initial problems in organ perfusion, Miss R Busio for her extensive and enthusiastic contributions to the autoradiographic work, $\mathrm{Dr}$ G J A M Strous for fruitful discussions and for criticising this paper, Miss C Pieksma for typing this manuscript, and Mr F Zwaan for care of the animals.

\section{References}

${ }^{1}$ De Groot ECBM. The relation between synthesis and secretion of pepsinogen. Utrecht, The Netherlands: Thesis, 1974.

${ }^{2}$ Kramer MF, Geuze JJ. Glycoprotein transport in the surface mucous cells of the rat stomach. J Cell Biol 1977; 73: 533-47.

${ }^{3}$ Parsons ME. Studies on gastric acid secretion using an isolated whole mammalian stomach in vitro. J Physiol (Lond) 1975; 247: 35-6P.

${ }^{4}$ Davenport, HW. Chavré VJ. Conditions affecting acid secretion by mouse stomachs in vitro. Gastroenterology 1950; 15: 467-80.

${ }^{5}$ Dikstein S, Sulman FG. Rat stomach preparation in vitro. Biochem Pharmacol 1965; 14: 355-7.

${ }^{6}$ Menguy R, Masters YF. Mechanisms of stress ulcer: influence of hypovolemic shock on energy metabolism in the gastric mucosa. Gastroenterology 1974; 66: 46-55.

${ }^{7}$ Birkett D, Silen W. Effect of severe anoxia on the permeability of the gastric mucosa. Proc Soc Exp Biol Med 1975; 148: 256-60.

${ }^{8}$ Gollan F, Clark LC. Organ perfusion with fluorocarbon fluid. The Physiologist 1966; 191.

${ }^{9}$ Ruigrok TJC, Elbers PF. Ultrastructural changes after perfusion of isolated rat liver with a fluorocarbon emulsion as a substitute for erythrocytes. Cytobiologie 1970; 2: 315-25.

${ }^{10}$ Symposium on fluorocarbons II. Fed Proc 1975; 34, no. 6.

"Munro DR. Route of protein loss during a model proteinlosing gastropathy in dogs. Gastroenterology 1974; 66: 960-72.

${ }^{12}$ Folkman J, Cole P, Zimmerman S. Tumor behaviour in isolated perfused organs: in vitro growth and metastases of biopsy material in rabbit thyroid and canine intestinal segment. Ann Surg 1966; 164: 491-502.

${ }^{13}$ Anson ML. The estimation of pepsin, trypsin, papain and cathepsin with hemoglobin. J Gen Physiol 1938; 22: 79-89.

${ }^{14}$ Richardson KC, Jarett L, Finke EH. Embedding in epoxy resins for ultrathin sectioning in electronmicroscopy. Stain Technol 1960; 35: 313-23.

${ }^{15}$ Zander R. $\mathrm{O}_{2}$-Löslichkeit in Fluorocarbonen. Res Exp Med 1974; 164: 97-109.

${ }^{16}$ Van Huis GA, Kramer MF. Glycoprotein synthesis in the mucous cells of the vascularly perfused rat stomach, I. Surface mucous cells. Am J Anat 1979; 156: 301-12.

${ }^{17}$ Ritchie HD, Hardcastle JD. Isolated organ perfusion. London: Crosby Lockwood Staples, 1973.

${ }^{18}$ Ross BD. Perfusion techniques in biochemistry. Oxford: Clarendori Press, 1972.

${ }^{19}$ Dritsas KG, Kowalewski K. Perfusion of the isolated canine stomach. Br J Surg 1966; 53: 732-5.

${ }^{20}$ Kowalewski K, Scharf R. Secretion of hydrochloric acid by ex vivo isolated canine stomach. Scand J Gastroenterol 1971 ; 6: 675-81.

${ }^{21}$ Moody FG, Gilder H, Beal JM. Perfusion secretory studies of the isolated canine stomach. Surg Forum 1963; 13: 282-4.

${ }^{22}$ Salmon, PA, Assimacopoulos CA. Perfusion of the isolated canine stomach. A preliminary report. Surg Res 1964; 4: 339-48.

${ }^{23}$ Way LW, Hawley PR. Isolated perfusion of canine stomach. Surg Gynecol Obst 1969; 129: 1005-13.

${ }^{24}$ Davenport HW, Kaufman GL. Plasmashedding by the canine oxyntic and pyloric glandular mucosa induced by topical action of acetylcholine. Gastroenterology 1975; 69: 190-7.

${ }^{25}$ Pilot M. Acid secretion from the completely isolated blood perfusion canine stomach. J Physiol 1979; 296: 113-24.

${ }^{26}$ Wattel W, Van Huis GA, Kramer MF, Geuze JJ. Glycoprotein synthesis in the mucous cells of the vascularly perfused rat stomach. II. Differentiating mucous cells. Am J Anat 1979; 156: 313-20.

${ }^{27}$ Dawson AMC, Elliott DC, Elliott WH, Jones KM. Data for biochemical research. Oxford: Clarendon Press, 1959.

${ }^{28}$ Babad H, Ben Zvi R, Bdolah A, Schramm M. The mechanism of enzyme secretion by the cell. Eur J Biochem 1967; 1: 96-101.

${ }^{29}$ Manchester KL, Wool JG. Insulin and incorporation of amino acids into proteins of muscle, II. Accumulation and incorporation studies with the perfused rat heart. Biochem J 1963; 89: 202-9. 